\title{
MATHEMATICAL MODEL AND OPERATION MODES OF DRUM-TYPE BIOFERMENTER
}

\author{
Roman Uvarov $^{1}$, Aleksandr Briukhanov ${ }^{1}$, Aleksandr Spesivtsev ${ }^{2}$, Vasiliy Spesivtsev ${ }^{3}$ \\ ${ }^{1}$ Institute for Engineering and Environmental Problems in Agricultural Production - IEEP, Russia; \\ ${ }^{2}$ A.F.Mozhaisky Military Space Engineering Academy, Russia; \\ ${ }^{3}$ North-West Regional Scientific Centre, Russia \\ rauvarov@gmail.com, sznii@yandex.ru,sav2050@gmail.com
}

\begin{abstract}
One of the most effective technologies for manure utilization is its processing in a drum biofermenter. This technology allows obtaining different products with specified end-use properties in the same installation depending on the operation mode. The created mathematical model is designed to determine the modes, under which the bio-fermentation processes in the processed material are most intensive and feature the least nutrients loss. The model input factors were aeration time (from 3 to $7 \mathrm{~min} \cdot \mathrm{h}^{-1}$ per one ton), aeration rate (from 5.5 to $9.5 \mathrm{~m} \cdot \mathrm{s}^{-1}$ under the $76 \mathrm{~mm}$ pipeline diameter) and drum rotation frequency (three rotations every 6 to 12 hours). The target function was the product temperature reached in the bio-fermenter during manure processing. Experiments with three replications were carried out in the laboratory of bioconversion of organic waste in IEEP on a patented drum bio-fermenter. The starting material was separated solid fraction of cattle manure. Based on the calculation results the error of experiment reproducibility was 1.85 . The developed mathematical model allows establishing the effect of individual input factors and their combinations on the target function. After the model analysis the pair interaction of time and aeration rate factors were found to have the most sizable contribution to the temperature variation in the bio-fermenter. The rational modes of drum biofermenter operation were identified to obtain different end products with desired properties and to further optimize the conversion process.
\end{abstract}

Key words: manure, bio-fermentation, mathematical model, drum bio-fermenter, ecology.

\section{Intoduction}

Livestock production is directly associated with manure formation. Every year its utilisation is becoming an increasingly significant problem. In the North-West of the Russian Federation composting is the basic manure utilisation technique. It allows to obtain the high quality organic fertilizer, which forms the basis for extension of the humus layer of soil and subsequent increase of crop yields [1].

Intensification of livestock industry toughens the requirements for the manure utilization technology forcing to introduce new, faster and more efficient processing practices. One such technology is accelerated manure composting in a drum bio-fermenter.

The basic condition for successful composting is to provide the microorganisms, involved in aerobic fermentation of manure, with the most comfortable living conditions: sufficient amount of oxygen and optimum temperature [2]. Specific design features of a drum bio-fermenter allow to vary its operation modes in order to receive different products with desired final properties: organic fertilizers or bedding for farm animals [3; 4].

The aim of the work was to create a mathematical model of a drum bio-fermenter and to determine the rational modes of its operation to produce bedding and fertilizers.

\section{Materials and methods}

The study was conducted in 2015-2016 in the IEEP Organic Waste Bioconversion Laboratory on a patented drum-type bio-fermenter (Fig. 1) [5]. Bio-fermenter is a revolving drum with insulating coating, mounted on a fixed frame with the help of rollers. The driving system includes the power unit and the motor reduction unit. The aeration system of the composted mass is a perforated pipe placed inside the drum along its full length. Special blades are evenly spaced around the inner diameter of the drum to direct the ready compost to the discharging auger.

The laboratory-scale model of the bio-fermenter with the dimensions of $4300 \times 2100 \times 1650 \mathrm{~mm}$, effective capacity of $2.2 \mathrm{~m}^{3}$, and the daily output of $0.7 \mathrm{~m}^{3}$, allows to investigate the biofermentation process of different types of organic waste in the real time mode. 


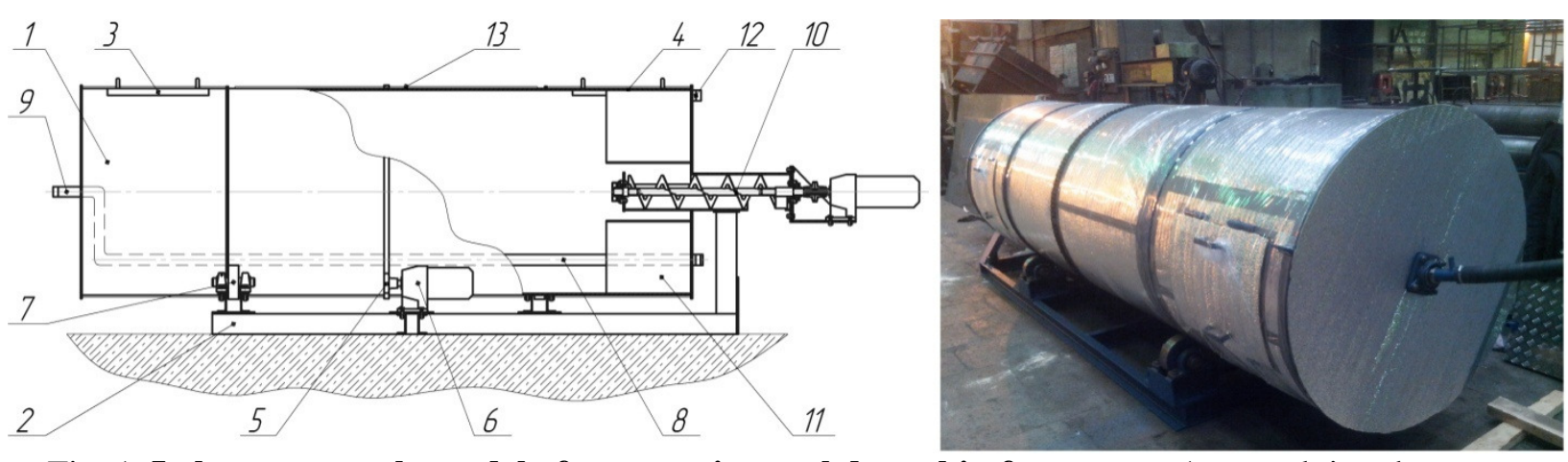

Fig. 1. Laboratory-scale model of an experimental drum bio-fermenter: 1 - revolving drum;

2 - frame; 3 - charge hole; 4 - checking hole; 5 - power unit; 6 - motor reduction unit; 7 - mounting assemble; 8 - aeration pipe; 9 - air duct for outside air supply; 10 - discharging auger conveyor; 11 - blades; 12 - exhaust duct; 13 - heat insolation

Initial raw material in the study was solid fraction of cattle manure from a dairy farm with the animal stock of 900 heads, manure output of $90 \mathrm{~m}^{3} \cdot \mathrm{day}^{-1}$ and the system of manure separation into solid and liquid fractions in place.

The raw material and final product were analysed in the analytical laboratory of IEEP.

The experiment was conducted under a cyclic operation mode of the bio-fermenter with three replications. The experimental design technique [6] was implemented in the study, with the optimisation factor being the self-heating temperature of the composted mass in the bio-fermenter.

Amount of the composted material of $1240 \mathrm{~kg}$ was taken with due account for the minimal critical mass values required for the successful conversion process [7] and the design features of the laboratory-scale bio-fermenter.

Dynamic pattern of temperature, mass, humidity and chemical composition was recorded in the real time mode. The matrix of full factorial experiment of the $2^{n}$ type was implemented, where $n=3$ is the number of input variables (Table 2). To improve the accuracy and reliability of the obtained results, each experiment consisted of three parallel replications. The experiments were carried out using randomization.

The following equipment was used in the experiment: ТЦМ 9410/M2 thermometer with $\pm 0.5{ }^{\circ} \mathrm{C}$ sensitivity; strain sensor 3410-2000-C3 with $0.02 \%$ error; laboratory scales Pioneer with $0.005 \%$ error; pH-meter/ionometer ЭКСПЕРТ-001 3(01) with $0.02 \%$ error, spectrophotometer ПЭ-5400 В with the accuracy of $0.001 \%$, as well as atomic absorption spectrophotometer Shimadzu AA-680, with $0.001 \%$ error.

During the experiment the ambient temperature was maintained at a constant level of $15 \pm 1{ }^{\circ} \mathrm{C}$.

In the experiment the phenomenon of bio fermentation of organic waste was investigated in terms of creating the most favourable conditions for the development of microorganisms. The previous research has shown that from 5.2 to $7.4 \mathrm{~m}^{3}$ of air are required to decompose one $\mathrm{kg}$ of organic matter and the method of air supply to the processed material is of great importance [8; 9]. In view of this, the input factors (independent variables) were selected, which had the strongest impact on the process of accelerated composting in a drum biofermenter: aeration time, aeration rate and drum rotation interval. Table 1 presents the variability intervals of independent variables, with the accepted measurement units being indicated.

Table 1

Variability intervals of independent variables

\begin{tabular}{|c|c|c|c|c|c|}
\hline $\begin{array}{c}\text { Variable } \\
\text { code }\end{array}$ & Variable name & $\begin{array}{c}\text { Measurement } \\
\text { unit }\end{array}$ & $\begin{array}{c}\text { mi } \\
\mathbf{n}\end{array}$ & $\begin{array}{c}\text { ma } \\
\mathbf{x}\end{array}$ & $\begin{array}{c}\text { Variability } \\
\text { interval }\end{array}$ \\
\hline $\mathrm{X}_{1}$ & Aeration time & $\mathrm{min} \cdot \mathrm{h}^{-1}$ & 3 & 7 & 4 \\
\hline $\mathrm{X}_{2}$ & Aeration rate & $\mathrm{m} \cdot \mathrm{s}^{-1}$ & 5.5 & 9.5 & 4 \\
\hline $\mathrm{X}_{3}$ & Drum rotation interval & Hour & 6 & 12 & 6 \\
\hline
\end{tabular}


The temperature of the composted mass in the biofermenter as an indicator of the processing intensity was accepted as dependent variable $Y\left({ }^{\circ} \mathrm{C}\right)$. The properties, purpose and quality of the final product depend on the stable temperature control.

In fertilizer production the key objective is to retain the maximum amount of nutrients in the end product. Under $62.5{ }^{\circ} \mathrm{C}$ protein coagulation and degradation of nutrient compounds take place that have an adverse effect on the product quality [10]. In bedding production a more important factor is its moisture-retaining capacity. So, here the priority objective is to reduce the moisture content of the end product that is achieved through higher temperature.

\section{Results and discussion}

The matrix of the full factorial experiment is presented in Table 2.

The values of the dependent variable $Y$ are given as the average of three parallel determinations, or which additional error of reproducibility was calculated.

Table 2 shows all independent variables in the standardised form:

$$
x_{i}=\frac{X_{i}-\bar{X}_{i}}{\Delta X_{i}},
$$

where $X_{i}$ and $\bar{X}_{i}-$ correspondingly coded and measured values of the input variable;

$\Delta X_{i}$ - variability interval.

Matrix of the full factorial experiment

\begin{tabular}{|c|c|c|c|c|}
\hline \multirow{2}{*}{ No. } & $\begin{array}{c}\text { Aeration } \\
\text { time }\end{array}$ & $\begin{array}{c}\text { Aeration } \\
\text { rate }\end{array}$ & $\begin{array}{c}\text { Drum rotation } \\
\text { interval }\end{array}$ & $\begin{array}{c}\text { Temperature in } \\
\text { bio-fermenter }\end{array}$ \\
\cline { 2 - 5 } & $x_{1}$ & $x_{2}$ & $x_{3}$ & Y \\
\hline 1 & -1 & -1 & -1 & 53.17 \\
\hline 2 & 1 & -1 & -1 & 72.33 \\
\hline 3 & -1 & 1 & -1 & 65.60 \\
\hline 4 & 1 & 1 & -1 & 46.70 \\
\hline 5 & -1 & -1 & 1 & 41.50 \\
\hline 6 & 1 & -1 & 1 & 66.33 \\
\hline 7 & -1 & 1 & 1 & 60.50 \\
\hline 8 & 1 & 1 & 1 & 52.10 \\
\hline
\end{tabular}

Processing of obtained results from Table 2 by experimental design techniques resulted in a mathematical model of accelerated composting in a drum-type bio-fermenter:

$$
Y=57.279+2.088 x_{1}-2.171 x_{3}-8.913 x_{1} x_{2}+2.021 x_{1} x_{3}+2.246 x_{2} x_{3}
$$

Based on the calculation results the experiment reproducibility error was $S_{\text {repr }}=1.844$.

The model only shows significant coefficients, which exceed $S_{\text {repr }}$

The model was verified on the statistical experimental data, which were obtained during the biofermenter operation $[4 ; 11]$.

The model analysis revealed the two-factor interaction of $x_{1} x_{2}$ (time and aeration rate factors) to have the most sizable contribution to the temperature variation $Y$. This interaction has a completely physical meaning since it determines the amount of oxygen supplied into the reaction zone in the biofermenter. The interaction $x_{2} x_{3}$ is also explainable and determines the efficiency of oxygen delivery to the microorganisms in the whole compost mass. The contribution of the remaining variables to the variation of $Y$ is approximately the same. This conclusion fully complies with the bio-fermentation concept.

The coefficient of the constant term is exponentially higher than the other significant coefficients and, in addition, the coefficient of the two-factor interaction $x_{1} x_{2}$ is greater than the other coefficients in the modulus. The theory of the experiment design states that the yield surface of the phenomenon 
under study represents "nearly stationary region" [12]. In this context, according to the theory of the experiment design it is no longer expedient or practical to conduct the steep ascent since the practical objective of the study was to find model-rational modes for two regulated temperatures of 60 and $80^{\circ} \mathrm{C}$, underlying the production of qualitatively different products [13; 14].

The obtained mathematical expression (2) adequately describes the main indicator of the process, and is thus a model of the phenomenon under consideration - the temperature of the composted mass in the biofermenter. It gives a reasonable possibility to calculate the rational operation modes of the drum biofermenter. The calculation and actual results are shown in Table 3.

Table 3

Rational operation modes of a drum-type bio-fermenter

\begin{tabular}{|c|c|c|c|c|c|}
\hline \multirow{3}{*}{ Mode } & \multirow{2}{*}{$\begin{array}{c}\text { Aeration } \\
\text { time, } \\
\min ^{-1} h^{-1}\end{array}$} & \multirow{2}{*}{$\begin{array}{l}\text { Aeration } \\
\text { rate, } \mathbf{m} \cdot \mathbf{s}^{-1}\end{array}$} & \multirow{2}{*}{$\begin{array}{l}\text { Drum rotation } \\
\text { interval, hour }\end{array}$} & \multicolumn{2}{|c|}{ Temperature in bio-fermenter, $\stackrel{\circ}{-}$} \\
\hline & & & & Calculated & Actual \\
\hline & $\mathrm{X}_{1}$ & $\mathrm{X}_{2}$ & $\mathrm{X}_{3}$ & $\mathrm{Y}_{\mathrm{C}}$ & $\mathrm{Y}_{\mathrm{A}}$ \\
\hline $\mathrm{I}$ & 9 & 5.0 & 6 & 80.19 & 79.2 \\
\hline II & 10 & 5.0 & 12 & 82.80 & 82.9 \\
\hline III & 10 & 5.5 & 8 & 79.41 & 78.1 \\
\hline IV & 7 & 2.0 & 8 & 80.80 & 81.4 \\
\hline $\mathrm{V}$ & 3 & 9.5 & 12 & 61.20 & 62.8 \\
\hline VI & 3 & 8.5 & 8 & 60.06 & 58.9 \\
\hline VII & 7 & 6.5 & 12 & 60.84 & 61.2 \\
\hline VIII & 5 & 5.5 & 6 & 61.70 & 63.5 \\
\hline IX & 4 & 9.5 & 12 & 59.28 & 60.3 \\
\hline
\end{tabular}

The created model allowed to identify the rational operation modes of a drum bio-fermenter: to produce bedding - mode II (aeration time $10 \mathrm{~min} \cdot \mathrm{h}^{-1}$; aeration rate $5 \mathrm{~m} \cdot \mathrm{s}^{-1}$; drum rotation interval 12 hour); to produce the organic fertiliser - mode VII (aeration time $7 \mathrm{~min} \cdot \mathrm{h}^{-1}$; aeration rate $6.5 \mathrm{~m} \cdot \mathrm{s}^{-1}$; drum rotation interval 12 hour). The F-test statistics proved the high accuracy of the model.

The self-heating intensity of the processed material varied depending upon the applied operation mode (Fig. 2).
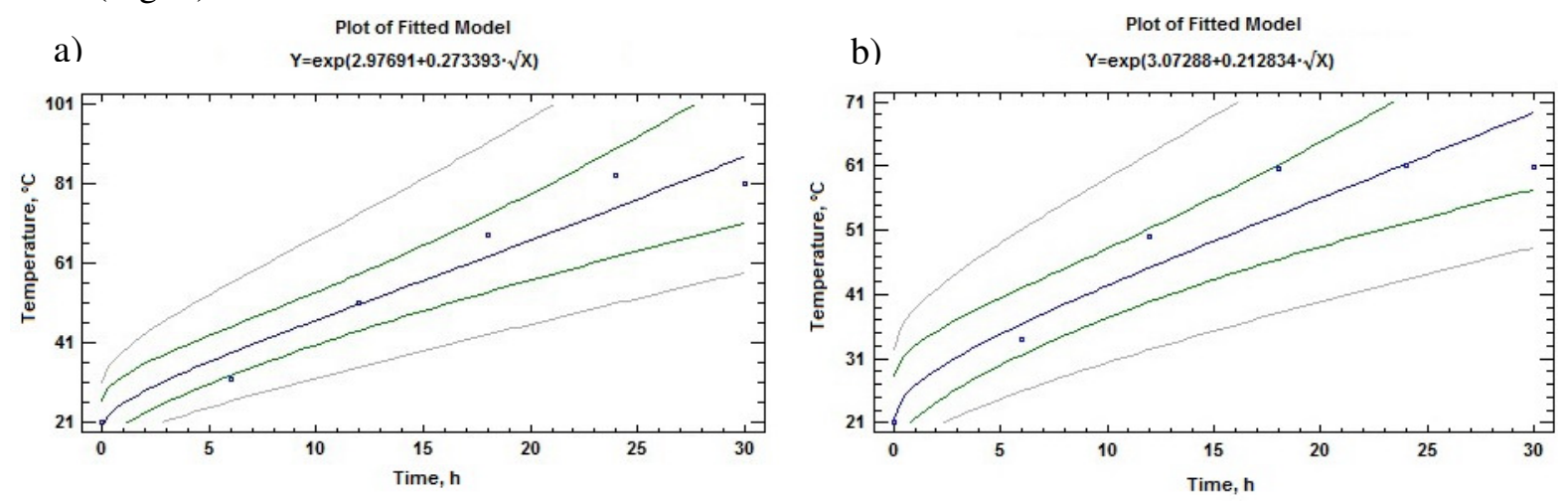

Fig. 2. Self-heating process in a drum bio-fermenter: $a$ - mode II; $b$ - mode VII

The analysis revealed that the required values of temperature can be achieved by various combinations of factors, which are decisive for the operating modes. For example, the desired temperature of $80^{\circ} \mathrm{C}$ to produce bedding may be achieved by different values of $X_{3}$ - drum rotation interval of 6,8 and 12 hours. However, in this case the aeration rate $X_{2}$ varies in the range of 2-5. $5 \mathrm{~m} \cdot \mathrm{s}^{-1}$, and the aeration time $X_{1}$ varies in the range of 7 to $10 \mathrm{~min}$.

The required temperature of $60^{\circ} \mathrm{C}$ may be achieved at lower values of $X_{1}$, but in this case the aeration rate $X_{2}$ increases. This confirms the effect of the oxygen amount as the main indicator of the bio fermentation process. 
If we take the value of the variable $X_{3}=12$ hours to be rational, in this case again it is possible to achieve the desired results.

In the operation mode IV, the required temperature is achieved under the aeration rate below the minimum. Consequently, other operation modes feature the surplus amount of oxygen in the biofermenter. To clarify this phenomenon more research is needed.

\section{Conclusions}

1. One of the most promising technologies for utilisation of solid fraction of cattle manure is the technology of accelerated composting in a drum biofermenter. This technology allows to obtain a product with desired final properties (organic fertilizer or bedding for farm animals) in a short time and with minimal loss of nutrients.

2. A laboratory-scale model of the drum biofermenter was designed and manufactured to study and to vary the operation modes.

3. Based on the study outcomes an adequate mathematical model of accelerated composting in the drum biofermenter was created.

4. The created model allowed to select the most rational operation modes of the biofermenter to produce bedding (aeration time $10 \mathrm{~min} \cdot \mathrm{h}^{-1}$; aeration rate $5 \mathrm{~m} \cdot \mathrm{s}^{-1}$; drum rotation interval 12 hour) and the organic fertiliser (aeration time $7 \mathrm{~min} \cdot \mathrm{h}^{-1}$; aeration rate $6.5 \mathrm{~m} \cdot \mathrm{s}^{-1}$; drum rotation interval 12 hour).

5. To verify the obtained data it is scheduled to test the biofermenter in the production environment on a dairy farm, with the output of solid fraction of cattle manure being 18.2 tons per day and the moisture content being $70 \%$.

\section{References}

1. Bryukhanov A.Yu. et. al. Russia. Status of nutrient bookkeeping in the Baltic Sea countries. Dessau-Roßlau, Umweltbundesamt Publishers, 2015, pp. 33-35.

2. Bahman E. Composting Manure and Other Residues. Waste Management. 1997, vol. 8, 180 p.

3. Уваров Р.А. Определение потерь питательных веществ при переработке подстилочного птичьего помета в биоферментационной установке барабанного типа (Nutrient loss during the bedding poultry manure bioconversion in a drum type installation). Bulletin of the All-Russian Scientific Research Institute of Livestock Mechanization. 2015, No 4(20), pp. 145-148. (in Russian).

4. Уваров Р.А. Результаты исследования возможности рециклинга твердой фракции навоза КРС в подстилку (Research results of recyclability of solid cattle manure into bedding). Innovations in agriculture. 2015, No 5 (15), pp. 174-178. (in Russian).

5. Брюханов А.Ю., Васильев Э.В., Максимов Н.В., Уваров Р.А. Биореактор для конверсии органических отходов непрерывного действия (Continuous-action bioreactor for conversion of organic waste materials). Patent RU 146604. 03.06.2014.

6. Хартман К., Лецкий Э., Шеффер В. Планирование эксперимента в исследованиях технологических процессов (Planning of Experiment in Research of Technological Processes). Moscow, Mir Publishers, 1977, 552 p. (in Russian).

7. Uvarov R., Briukhanov A., Shalavina E. Study Results of Mass and Nutrient Loss in Technologies of Different Composting Rate: Case of Bedding Poultry Manure. Engineering for Rural Development 2016, pp. 851-857.

8. Афанасьев В.Н. Обоснование и разработка технологий и технических средств для производства экологически безопасных, биологически активных удобрений на основе отходов животноводства и птицеводства (Substantiation and development of technologies, machines and equipment for production of environmentally safe, biologically active fertilisers based on animal and poultry waste) Thesis in the form of a scientific report for the degree of Doctor of Sciences (Engineering). St. Petersburg-Pushkin, 2000, 80 p. (in Russian).

9. Selimbasic, V., Marić, S., Petric, I., Djozic, A. Anaerobic Batch Fermentation of Cattle Manure. Effect of Ammonia. Journal of Environmental Protection and Ecology. 2012, No 13(1). pp. 211-218. 
10. Ковалев Н.Г, Барановский И.Н. Органические удобрения в XXI веке: биоконверсия органического сырья (Organic fertilizers in the XXI century: bioconversion of organic material). Tver, ChuDo Publishers, 2006, 304 p. (in Russian).

11. Уваров Р.А. Биоферментация помёта в установках закрытого типа (Bio-Fermentation of Poultry Manure in Closed Installation). Journal of Poultry Farming. 2016, No 10, pp. 53-56. (in Russian).

12. Налимов В.В., Чернова Н.А. Статистические методы планирования экстремальных экспериментов (Static Methods of Planning of Extreme Experiments). Moscow, Nauka Publishers, 1965, 340 p. (in Russian).

13. Брюханов А.Ю., Уваров Р.А. Математическая модель технологии ускоренного компостирования отходов животноводства в биоферментационных установках закрытого типа (Mathematical model of accelerated composting technology of farm animal waste in closed type installations). KGTU News, 2016, No 41, pp. 137-147. (in Russian).

14. Уваров Р.А. Обоснование оптимальных параметров и режимов работы биоферментационной установки барабанного типа для переработки навоза КРС (Substantiation of optimum parameters and operating modes of drum type bio-fermentation for processing of cattle manure). Bulletin of the All-Russian Scientific Research Institute of Livestock Mechanization, 2016, No 4(24), pp. 151-157. (in Russian). 